\title{
ІНФОРМАТИЗАЦІЯ ЗАКЛАДІВ ОХОРОНИ ЗДОРОВ'Я ЯК ОСНОВА ЕФЕКТИВНИХ КОМУНІКАЦІЙ В СИСТЕМІ ОХОРОНИ ЗДОРОВ'Я
}

\author{
М. А. Знаменська ${ }^{1}$, Г. О. Слабкий ${ }^{2}$ \\ Український інститут стратегічних досліджень МОЗ України ${ }^{1}$, м. Київ \\ Ужгородський національний університет
}

\begin{abstract}
Встановлено низький рівень комп'ютеризації закладів охорони здоров'я першого та другого рівнів надання медичної допомоги та більш високий - третинного рівня медичної допомоги. При цьому встановлено низький рівень доступу до мережі Інтернет закладів охорони здоров'я первинного та значно вищий - закладів вторинного та третинного рівнів медичної допомоги. Існуючий рівень інформатизації закладів охорони здоров'я не дозволяє впровадити ефрективну систему комунікацій в охороні здоров'я.
\end{abstract}

Ключові слова: заклади охорони здоров'я, комп'ютеризація, доступ до мережі Інтернет, рівень.

\section{ИНФОРМАТИЗАЦИЯ УЧРЕЖДЕНИЙ ЗДРАВООХРАНЕНИЯ КАК ОСНОВА ЭФФЕКТИВНЫХ КОММУНИКАЦИЙ В СИСТЕМЕ ЗДРАВООХРАНЕНИЯ}

\author{
М. А. Знаменская ${ }^{1}$, Г. А. Слабкий \\ Украинский институт стратегических исследований МЗ Украины ${ }^{1}$, г. Киев \\ Ужгородский национальный университет²
}

\begin{abstract}
Установлен низкий уровень компьютеризации учреждений здравоохранения первого и второго уровней оказания медицинской помощи и более высокий - третичного уровня медицинской помощи. При этом установлен низкий уровень доступа к сети Интернет учреждений здравоохранения первичного и значительно выше - учреждений вторичного и третичного уровней медицинской помощи. Существующий уровень информатизации учреждений здравоохранения не позволяет внедрить эффективную систему коммуникаций в здравоохранении.
\end{abstract}

Ключевые слова: учреждения здравоохранения, компьютеризация, доступ к сети Интернет, уровень.

\section{INFORMATIZATION OF HEALTH CARE INSTITUTIONS AS A BASIS FOR EFFECTIVE COMMUNICATION IN HEALTH CARE SYSTEM}

\author{
M. A. Znamenska', G. O. Slabkiy ${ }^{2}$ \\ Ukrainian Strategic Studies Institute of the Ministry of Health Ukrayiny ${ }^{1}, m$. Kyiv \\ Uzhhorod National University ${ }^{2}$
}

\begin{abstract}
A low level of computerization of primary and secondary health care and a higher level in tertiary health care is shown. At the same time a low level of Internet access in primary health care institutions and much higher - in institutions of secondary and tertiary levels of health care is shown. The current level of informatization does not allow health care institutions to implement an effective system of communication in healthcare.
\end{abstract}

Key words: health care, computerization, Internet access, level.

Державна політика в Україні щодо інформатизації системи охорони здоров'я, а також впровадження новітніх інформаційних технологій спрямовані на ліквідацію відставання в цій сфері від передових світових держав і прискорення входження в інформаційний простір міжнародного співтовариства 3 метою підняття управління охороною здоров'я, прак- тичної медицини, медичної освіти і науки на сучасний рівень $[2,7,10]$.

Для України актуальними є питання розробки стратегії формування та подальшого вдосконалення відомчої інформаційної системи відповідно до вимог єдиного інформаційного простору країни, а об'єкт інформатизації розглядається як складова час- 
тина інформаційної структури держави [1] та сукупність різноманітних структур і форм їх взаємодії щодо збору, обробки, збереження, розповсюдження та використання різних видів інформації з метою підтримки прийняття рішень і задоволення інтересів громадян в отриманні якісної та ефективної медичної допомоги [3, 4, 8, 9].

Досягнення вказаних цілей можливе через створення дієвої системи комунікацій, основою якої мають стати інформаційні технології $[5,6]$.

Мета роботи: вивчити рівень комп'ютеризації та інформатизації закладів охорони здоров'я різних рівнів надання медичної допомоги як фактора, який сприяє запровадженню ефективної системи комунікацій в охороні здоров'я.

Матеріали та методи. В ході виконання роботи використані результати оперативного моніторингу стану комп'ютеризації та інформатизації закладів охорони здоров'я України, який проводить Український інститут стратегічних досліджень МО3 України.

Результати та їх обговорення. На першому етапі дослідження було вивчено рівень забезпеченості закладів охорони здоров'я різного рівня медичної допомоги персональними комп'ютерами. На первинному рівні надання медичної допомоги, враховуючи специфіку діяльності сімейних лікарів, вивчали рівень забезпечення у відповідності до кількості лікарів первинного рівня медичної допомоги. На вторинному та третинному рівнях вивчали забезпечення персональними комп'ютерами структурних підрозділів вказаних закладів охорони здоров'я. Отримані результати наведені в таблиці 1.

3 наведених в таблиці 1 результатів дослідження видно, що загалом в Україні за рівнями надання медичної допомоги найвищий рівень забезпечення персональними комп'ютерами є на третинному рівні (18,3\%), а найнижчий-на первинному (6,0 \%)рівні надання медичної допомоги. На вторинному рівні надання медичної допомоги рівень забезпеченості персональними комп'ютерами склав 6,0 \%.

Найвищі рівні забезпеченості персональними комп'ютерами за рівнями надання медичної допомоги зареєстровані в наступних регіонах:

- первинний рівень: 13,5 \% - Вінницька, 5,8 \% Закарпатська, 5,3 \%-Луганська, 5,1 \%-Івано-Франківська області;

- вторинний рівень: 9,4 \% - Дніпропетровська, 8,8 \% -Волинська, 8,4 \%-Донецька, 8,0 \%-Сумська області;
Таблиця 1. Забезпеченість закладів охорони здоров'я персональними комп'ютерами, \% (первинний рівень - до кількості лікарів; вторинний та третинний рівні - до кількості структурних підрозділів)

\begin{tabular}{|l|c|c|c|}
\hline \multirow{2}{*}{$\begin{array}{c}\text { Адміністративна } \\
\text { територія }\end{array}$} & \multicolumn{3}{|c|}{ Рівень медичної допомоги } \\
\cline { 2 - 4 } & первинний & $\begin{array}{c}\text { вторин- } \\
\text { ний }\end{array}$ & $\begin{array}{c}\text { третин- } \\
\text { ний }\end{array}$ \\
\hline Вінницька & 13,5 & 3 д & 17,8 \\
\hline Волинська & 3,4 & 8,8 & 15,9 \\
\hline Дніпропетровська & 4,1 & 9,4 & 28,6 \\
\hline Донецька & 5,0 & 8,4 & 40,1 \\
\hline Житомирська & 2,2 & 5,1 & 21,7 \\
\hline Закарпатська & 5,8 & 7,1 & 24,8 \\
\hline Запорізька & 0,1 & 4,8 & 9,5 \\
\hline Івано-Франківська & 5,1 & 4,1 & 12,8 \\
\hline Київська & 1,0 & 5,4 & 15,5 \\
\hline Кіровоградська & 0,8 & 5,2 & 21,3 \\
\hline Луганська & 5,3 & 7,8 & 21,1 \\
\hline Львівська & 4,7 & 4,7 & 13,7 \\
\hline Миколаївська & 2,9 & 4,0 & 12,1 \\
\hline Одеська & 2,2 & 3,9 & 21,6 \\
\hline Полтавська & 1,9 & 3,7 & 13,9 \\
\hline Рівненська & 0,2 & 4,9 & 14,4 \\
\hline Сумська & 3,6 & 8,0 & 20,0 \\
\hline Тернопільська & 1,2 & 1,2 & 1,3 \\
\hline Харківська & 3,5 & 6,7 & 21,9 \\
\hline Херсонська & 1,8 & 1,8 & 23,0 \\
\hline Хмельницька & 1,9 & 7,7 & 11,5 \\
\hline Черкаська & 2,7 & 4,1 & 14,7 \\
\hline Чернівецька & 1,9 & 2,1 & 7,6 \\
\hline Чернігівська & 1,6 & 7,9 & 20,1 \\
\hline м. Київ & 2,8 & 7,3 & 29,8 \\
\hline Усього & 3,0 & 6,0 & 18,3 \\
\hline
\end{tabular}

- третинний рівень: 40,1 \% - Донецька, 28,6 \% Дніпропетровська, 24,8 \% - Закарпатська області та 29,8\% -м.Київ.

Найнижчі рівні забезпеченності персональними комп'ютерами за рівнями надання медичної допомоги зареєстровані в наступних регіонах:

- первинний рівень: 0,1 \% - Запорізька, 0,2 \% Рівненська, 0,8 \% - Кіровогродська області;

- вторинний рівень: 1,2 \% - Тернопільська, 1,8 \% -Херсонська, 2,1 \% - Чернівецька області;

-третиннийрівень: 1,3\%-Тернопільська, 7,6 \%Чернівецька, 9,5 \% - Запорізька області.

Далі вивчали питання доступності в закладах охорони здоров'я доступу до мережі Інтернет. Рівень доступу до мережі Інтернет встановлювали із числа закладів охорони здоров'я, які комп'ютеризовано. Отримані в ході дослідження дані наведено в таблиці 2. 
Таблиця 2. Забезпеченість 303 первинного рівня доступом до мережі Інтернет, \%

\begin{tabular}{|l|c|c|c|}
\hline \multirow{2}{*}{$\begin{array}{c}\text { Адміністративна } \\
\text { територія }\end{array}$} & \multicolumn{3}{|c|}{ Рівень медичної допомоги } \\
\cline { 2 - 4 } & $\begin{array}{c}\text { первин- } \\
\text { ний }\end{array}$ & $\begin{array}{c}\text { вторин- } \\
\text { ний }\end{array}$ & $\begin{array}{c}\text { третин- } \\
\text { ний }\end{array}$ \\
\hline Вінницька & 100,0 & 100,0 & 100,0 \\
\hline Волинська & 0,6 & 76,0 & 100,0 \\
\hline Дніпропетровська & ІД & 80,0 & 100,0 \\
\hline Донецька & 1,2 & 100,0 & 100,0 \\
\hline Житомирська & 2,5 & 78,9 & 87,0 \\
\hline Закарпатська & 10,3 & 100,0 & 100,0 \\
\hline Запорізька & 0,2 & 100,0 & 100,0 \\
\hline Івано-Франківська & 2,3 & 73,5 & 84,4 \\
\hline Київська & 1,3 & 96,2 & 100,0 \\
\hline Кіровоградська & 0,8 & 92,0 & 100,0 \\
\hline Луганська & 10,4 & 53,4 & 97,1 \\
\hline Львівська & 2,8 & 59,3 & 96,4 \\
\hline Миколаївська & 2,5 & 69,1 & 82,4 \\
\hline Одеська & 4,1 & 80,3 & 100,0 \\
\hline Полтавська & 3,6 & 74,5 & 97,2 \\
\hline Рівненська & 0,6 & 100,0 & 79,5 \\
\hline Сумська & 2,6 & 100,0 & 100,0 \\
\hline Тернопільська & 0,9 & 89,0 & 78,6 \\
\hline Харківська & 100,0 & 100,0 & 100,0 \\
\hline Херсонська & 4,9 & 100,0 & 100,0 \\
\hline Хмельницька & 1,0 & 96,4 & 100,0 \\
\hline Черкаська & 6,6 & 72,2 & 32,0 \\
\hline Чернівецька & 4,0 & 100,0 & 100,0 \\
\hline Чернігівська & 2,0 & 100,0 & 100,0 \\
\hline м. Київ & 1,3 & 100,0 & 100,0 \\
\hline Усього & 10,1 & 87,5 & 93,8 \\
\hline
\end{tabular}

3 даних таблиці 2 видно, що всі комп'ютеризовані заклади охорони здоров'я первинного рівня надання медичної допомоги мають доступ до мережі Інтернет у Вінницькій та Харківській областях, а найнижчий показник, менше одного відсотка, у Волинській, Запорізькій та Рівненській областях. Загалом по Україні рівень доступності до мережі Інтернет за роки дослідження збільшився в 2,06 раза і склав у 2012 p. 10,1\%.

Різниця граничних показників рівня забезпеченості доступу до мережі Інтернет 303 первинного рівня надання медичної допомоги за регіонами країни $є$ достовірною і становить 166,7 раз.

Встановлено високий рівень доступу закладів охорони здоров'я вторинного рівня медичної допомоги до мережі Інтернет. Так, 30312 адміністративних територій (44,4 \%) мають повний доступ до мережі Інтернет. Найнижчі рівні доступу 303 вторинного рівня надання медичної допомоги до мережі Інтернет зафіксовані в Луганській $(53,4$ \%), Львівській (59,3\%) та Миколаївській $(69,1 \%)$ областях.
Різниця граничних показників рівня забезпеченості доступу до мережі Інтернет 303 вторинного рівня надання медичної допомоги за регіонами країни $є$ достовірною і становить 1,87 раз.

Також встановлено високий рівень забезпеченості закладів охорони здоров'я третинного рівня надання медичної допомоги доступом до мережі Інтернет. У 17 (62,96 \%) адміністративних територіях 303 третинного рівня надання медичної допомоги мають доступ до мережі Інтернет. Найнижчі рівні забезпеченості доступом до мережі Інтернет 303 третинного рівня надання медичної допомоги зафіксовані в Тернопільській $(78,6$ \%) та Рівненській (79,5\%) областях.

Різниця граничних показників рівня забезпеченості доступом до мережі Інтернет 303 третинного рівня надання медичної допомоги за регіонами країни не $\epsilon$ достовірною і становить 1,27 раз.

За даними Українського інституту стратегічних досліджень, основними проблемами інформатизації охорони здоров'я України та можливими шляхами їх вирішення $є$ наступні [11].

Основні проблемні питання:

- недостатня нормативно-правова база, яка регламентує впровадження та розвиток інформаційних технологій в охороні здоров'я;

- низький рівень фінансування процесу інформатизації, що не дає змоги здійснювати ефективну політику з модернізації технічного парку, інформаційнопрограмних засобів і розвитку телекомунікаційних технологій;

- наявність різних технічних засобів та інформаційно-програмного забезпечення, що використовується в системі охорони здоров'я і перешкоджає впровадженню типових рішень;

• низький рівень розвитку комунікаційних каналів належної потужності між 303 (у т.ч. відсутність якісного підключення до мережі Інтернет), що заважає створенню єдиної системи передачі медичних даних;

- низький рівень використання ліцензованих засобів, що гальмує процес інтеграції медичних інформаційних систем України в єдиний інформаційний простір Свропи.

Можливі шляхи вирішення:

- створення сучасної нормативно-правової бази інформатизації охорони здоров'я;

- створення організаційної структури і науковометодичного забезпечення інформатизації охорони здоров'я, формування єдиної багаторівневої системи медичних інформаційних стандартів, єдиної 
інформаційно-аналітичної, нормативно-правової і довідкової систем;

- створення баз даних, що містять детальну інформацію про пацієнтів, які доступні з усіх точок доступу всередині державної медичної інформаційної мережі, з дотриманням захисту персоніфікованої інформації;

- впровадження передових інформаційних технологій в організацію єдиної системи збору, зберігання і аналізу інформації за рахунок побудови глобальної мережі галузі;

- автоматизація процесу прийняття управлінських рішень на основі інформації, накопиченої в базах даних, розробка інформаційної системи оцінки якості та ефективності медичної допомоги;

- забезпечення доступу до інформації про кращі зразки клінічної практики для усіх практикуючих лікарів;

- надання фахівцям охорони здоров'я з планування й управління об'єктивної інформації про обсяги наданої допомоги і фактичні витрати при наданні різних видів медичної допомоги;

- розробка і впровадження відомчих, статистичних і медико-технологічних інформаційних систем та їх матеріально-технічний супровід (кожна з таких систем повинна мати можливість адаптації до інших систем на платформі єдиних стандартів обміну медичною інформацією. Такі засоби повинні підтримувати технологію перенесення нових рішень від одної системи до іншої, що дасть змогу тиражувати рішення і розвиватися функціональності системи без іiі зупинки);

- організація доступу населення до інформаційної системи охорони здоров'я і формування механізмів «зворотного зв'язку»;

- організація взаємодії з інформаційними системами інших міністерств і відомств.

Стратегія інформатизації охорони здоров'я України має повністю відповідати основним цілям галузі та сприяти збереженню здоров'я нації і забезпечувати ефективне управління галуззю охорони здоров'я.

Висновки. Встановлено низький рівень комп'ютеризації закладів охорони здоров'я першого та другого рівнів надання медичної допомоги та більш високий - третинного рівня медичної допомоги. При цьому виявлено низький рівень доступу до мережі Інтернет закладів охорони здоров'я первинного, та значно вищий - закладів вторинного та третинного рівнів медичної допомоги. Існуючий рівень інформатизації закладів охорони здоров'я не дозволяє впровадити ефективну систему комунікацій в охороні здоров'я.

С. М. Кривенко, О. Р. Ситенко // Україна. Здоров'я нації. - 2013. -№ 4 (28). - С. 101-106.

7. Кривенко С. М. Міжнародні підходи до комунікацій в охороні здоров'я / С. М. Кривенко // Актуальні питання формування здорового способу життя та використання оздоровчих технологій: матер, міжнар. наук.-практ. конф., м. Херсон, 30-31 трав. 2013 р.: тези доп. -Херсон, 2013. - С. 96-98.

8. Кривенко С. М. Сучасна структура функціональноорганізаційної моделі інформатизації охорони здоров'я на регіональному рівні / С. М. Кривенко // Україна. Здоров'я нації. - 2014. - № 2 (30). - С. 75-82.

9. Мінцер О. П. Засади створення єдиної державної системи інформаційного забезпечення закладів охорони здоров'я / О. П. Мінцер, Л. Ю. Бабінцева, М. В. Банчук // Мед. інформатика та інженерія. - 2012. - №. 3. - С. 5-12. 10. Хвшцун А. I. Принципи формування єдиної медичної інформаційної системи великого міста / А. І. Хвшцун, В. О. Качмар // Мед. інформатика та інженерія. - 2009. № 3. - С. 39-47.

11. Щорічна доповідь про стан здоров'я населення, санітарно-епідемічну ситуацію та результати діяльності системи охорони здоров'я України. 2014 рік / за ред. Квіташвілі О. ; МОЗ України, ДУ «УІСД МОЗ України». -К., $2015 .-460 \mathrm{c}$. 